\title{
Neuropsychological assessment of language functions during functional magnetic resonance imaging - development of new tasks. Preliminary report
}

\author{
Opracowanie metod neuropsychologicznej oceny różnych aspektów czynności mowy \\ badanych w czasie neuroobrazowania przy zastosowaniu funkcionalnego rezonansu \\ magnetycznego. Doniesienie wstępne
}

Ewa Fersten', Maciej Jakuciński', Radosław Kuliński', Henryk Koziara ${ }^{3}$, Barbara Mroziak4, Paweł Nauman ${ }^{5}$

\author{
IInstyłut Medycyny Doświadczalnej i Klinicznej, Polska Akademia Nauk \\ 2Zakład Medycyny Nuklearnej i Rezonansu Magnetycznego, Wojewódzki Szpital Bródnowski w Warszawie \\ ${ }^{3}$ Klinika Neurochirurgii, Centrum Onkologii - Instyłut im. Marii Skłodowskiej-Curie w Warszawie \\ ${ }^{4}$ Zakład Psychologii i Promocii Zdrowia Psychicznego, Instytut Psychiatrii i Neurologii w Warszawie \\ 5Klinika Neurochirurgii, Instytut Psychiatrii i Neurologii w Warszawie
}

Neurologia i Neurochirurgia Polska 2011; 45, 6: 567-576

\section{Abstract}

Background and purpose: Due to the complex and extended cerebral organization of language functions, the brain regions crucial for speech and language, i.e. eloquent areas, have to be affected by neurooncological surgery. One of the techniques that may be helpful in pre-operative planning of the extent of tumour removal and estimating possible complications seems to be functional magnetic resonance imaging (fMRI). The aim of the study was to develop valid procedures for neuropsychological assessment of various language functions visualisable by fMRI in healthy individuals.

Material and methods: In this fMRI study, 10 healthy (with no CNS pathology), right-handed volunteers aged 25-35 were examined using four tasks designed to measure different language functions, and one for short-term memory assessment. A 1.5-T MRI scanner performing ultrafast functional (EPI) sequences with 4-mm slice thickness and 1-mm interslice gap was used to detect the BOLD response to stimuli presented in a block design (30-second alternating blocks of activity and rest). The analyses used the SPM software running in
\end{abstract}

\section{Streszczenie}

Wstęp i cel pracy: Przy złożonej i rozległej mózgowej organizacji funkcji mowy nowoczesna neuroonkologia operacyjna zmuszona jest wkraczać w obszary o największym znaczeniu dla jej przebiegu - w okolice elokwentne. Jedną z metod, która może być pomocna w przedoperacyjnym zaplanowaniu rozmiaru wycięcia guza i oszacowaniu powikłań, wydaje się technika funkcjonalnego obrazowania rezonansu magnetycznego (fMRI). Celem prowadzonych badań jest stworzenie trafnych metod neuropsychologicznej oceny u ludzi zdrowych różnych aspektów czynności mowy, możliwych do zobrazowania przy zastosowaniu fMRI.

Materiał i metody: W przeprowadzonych badaniach fMRI u 10 zdrowych (bez patologii w obrębie ośrodkowego układu nerwowego), praworęcznych ochotników w wieku 25-35 lat opracowano i zastosowano cztery próby do badania funkcji językowych oraz próbę do badania pamięci krótkoterminowej. Badania prowadzono na aparacie o indukcji pola $1,5 \mathrm{~T}$, z wykorzystaniem ultraszybkich sekwencji czynnościowych (EPI) o grubości warstwy 4 mm i 1-milimetrowym odstępie między

Correspondence address: dr Ewa Fersten, Instyłut Medycyny Doświadczalnej i Klinicznej PAN, ul. Cegłowska 80, 01-806 Warszawa,

e-mail: ewmed@acn.waw.pl

Received: 24.01.2011; accepted: 20.06.2011 
a MATLAB environment, and the obtained data were interpreted by means of colour-coded maps superimposed on structural brain scans.

Results: For each of the tasks developed for particular language functions, a different area of increased neuronal activity was found.

Conclusions: The differential localization of function-related neuronal activity seems interesting and the research worth continuing, since verbal communication failure may result from impairment of any of various language functions, and studies reported in the literature seem to focus on verbal expression only.

Key words: fMRI, language functions, neuropsychological assessment.

\section{Introduction}

Many novel findings indicating the complexity of mechanisms that underpin speech and language are currently emphasized, and the localization of language functions in the human brain is assumed to have a dynamic character. Moreover, a system of various cerebral structures and their interconnections is considered to be the neural substrate of speech and language functions, and its effective functioning is considered to be a prerequisite of logical communication [1]. This approach implies that the damage to any part of the system may result in verbal communication disturbance, and that the disturbance type (or symptom pattern) will depend on the lesion localization. The problem of cortical organization of language functions is further complicated by individual differences in this respect and by differential involvement of the two cerebral hemispheres. The view about the left hemisphere advantage for speech in right-handed individuals does not seem to be fully corroborated nowadays, since more and more research findings indicate that both cerebral hemispheres are involved in speech and language functions, and clinical observations suggest that these functions can be subserved also by right-hemisphere structures, even in right-handers.

Such a complex and extended cerebral organization of language functions has an obvious consequence: namely, brain regions of key importance for speech and language, i.e. the so-called eloquent areas, have to be affected warstwami, z użyciem techniki BOLD i wykorzystaniem do prezentacji bodźców metody zblokowanej (w postaci 30-sekundowych bloków aktywności i odpoczynku). Wyniki przeanalizowano za pomocą programu statystycznego SPM, działającego w środowisku MATLAB, a następnie dokonywano interpretacji uzyskanych danych za pomocą map kodowanych kolorami nałożonych na obrazy strukturalne.

Wyniki: Stwierdzono obszary wzmożonej aktywności neuronalnej dla każdej przygotowanej próby. Dla każdego zadania/funkcji mowy zaobserwowano aktywację w innej, specyficznej okolicy.

Wnioski: Ponieważ dysfunkcje w zakresie różnych aspektów mowy mogą prowadzić do zaburzenia słownego komunikowania się, a w świetle danych z piśmiennictwa można sądzić, że analizie poddawana jest na ogół jedynie czynność nadawania mowy, otrzymane wyniki wydają się interesujące, a badania warte kontynuowania.

Słowa kluczowe: fMRI, aspekty czynności mowy, ocena neuropsychologiczna.

by neurooncological surgery. This risk is very probable, as many reports on long-term observation of patients particularly those diagnosed with well-differentiated cerebral gliomas - suggest that the most extensive tumour excision is necessary [2-4] and that despite the continuing progress in radio- and chemotherapy, the length of the patient's postoperative survival depends to a large degree on complete tumour removal [5-7]. The challenge in contemporary neurosurgery consists not only in the patients' survival time lengthening, but above all in maintaining their best quality of life possible. Therefore, the difficult decision about performing surgery for cerebral tumour in the regions important for human cognitive functioning, particularly those subserving speech and language, has to be preceded by careful preoperative planning of the extent of tumour removal and by estimating possible complications.

Functional magnetic resonance imaging (fMRI) seems to be particularly helpful in this respect. Despite still evident limitations of the method, preoperative fMRI examination is conducted in the world's leading neurooncology centres [8]. This technique utilizes both the effect of neuronal activation on local blood flow enhancement, and differential magnetic properties of oxy-and deoxyhaemoglobin (i.e. of haemoglobin depending on the blood oxygenation level). During activation of a particular cerebral area, metabolic processes and local blood flow are enhanced, while the level of deoxyhaemoglobin decreases. This results in a reduction of $\mathrm{T} 2$ 
shortening effects, and a local increase in signal intensity is seen. The phenomenon described in the early 1990s by Ogawa was called the blood oxygenation level-dependent (BOLD) contrast [9]. It is assumed that during performance of certain cognitive tasks evoking neuronal activation in particular areas of the brain, the local blood flow is enhanced and oxyhaemoglobin and deoxyhaemoglobin levels change in this region. These local changes are evidenced in the BOLD signal fluctuations. The technique allows one to produce a colour-coded map of neuronal activity areas for various human activities. Thus, an fMRI of the brain allows one to locate in alert subjects the functional cerebral areas specific to particular cognitive functions [10-13].

Development of tasks for the neuropsychological assessment of various language functions during fMRI examination of healthy adults should produce cortical maps of neuronal activation located in different areas, which would be not only of scientific interest (although their cognitive role should not be neglected), but also of pivotal practical importance. The fMRI scan results may provide neurosurgeons with important additional data on the location of cerebral structures crucial for language expression (speaking) or reception (speech comprehension), and their spatial relation to the CNS areas affected by the neoplastic process, especially by cerebral gliomas.

The aim of the study was to develop objective, valid procedures for neuropsychological assessment of various language functions using fMRI in healthy volunteers.

\section{Material and methods}

\section{Material and procedure}

Functional MRI involves a multistage and very complex examination that requires an extensive database capacity due to the amount of information to be processed. Considering the examination complexity, three detailed procedures were developed: preparatory, executive, and imaging. Due to the specific nature of each of the procedures, a different specialist is responsible for the performance of each stage: a neuropsychologist, computer scientist, and radiologist, respectively.

The fMRI examination requires an appropriately integrated system including an MRI scanner with a magnetic field induction of at least $1.5 \mathrm{~T}$, a stimulus presentation device, and software for analysing the collected data.
Five neuropsychological tasks have been designed for the purposes of the fMRI study to assess language functions (four tasks) and short-term memory traces, and above all, working memory (activation expected in prefrontal part of inferior frontal gyrus) (one task). The following tasks were used to assess language functions: (1) an ability to combine simple language units into more complex ones, and ability ensuring a smooth run of this process, i.e. reading (the task validity would be evidenced by activation expected in the inferior premotor cortex); (2) an ability to identify basic auditory units of spoken language, i.e. phonemes, or the so-called phonematic hearing (the task validity would be corroborated by activation of the posterior superior temporal gyrus); (3) an ability of dynamic organization of speech, i.e. verbal fluency (activation is expected, first and foremost, in the premotor structures); (4) association ability (analysis of this task is in progress).

Any activation that might systematically occur across subjects in any other cerebral areas beyond the expected sites would evidence the process complexity as well as the presence of individual differences.

Moreover, a finger-tapping task (FTT) was used as a reference test, best documented for its sensitivity. The aim of the FTT was to evaluate the subjects' motivation to perform the tasks.

In this BOLD fMRI study, the examination always consisted of two parts: in the first, so-called control condition, identification and registration of the brain activity were conducted when the subject was at rest, while in the second, experimental condition they were conducted during presentation of a specific stimulus. Registration of the brain activity associated with a specific activity under study was obtained by subtracting the brain image obtained during the control condition from that obtained under the experimental condition. The development of tasks loaded with the language factors under study to the degree that would produce a significant effect seems to be an essential prerequisite for the diagnostic process.

Designing tasks is followed by the next important stage of software application programming that would ensure not only stimulus presentation at appropriate temporal intervals, but also response registration.

Two approaches are currently used to obtain fMRI data: the block design and single trial method. Considering the type of stimuli used in our study and the MRI scanner capacity, the former approach was selected: each of the successive tasks was presented in six 30-second blocks followed by 30 -second intervals during which the subject was at rest, focusing on the fixation point in the 
middle of the screen. Thus, blocks of task-related activity were alternating with baseline activity blocks.

At the beginning of the MRI examination and before each series of 30-second blocks, instructions were displayed on the screen to explain the forthcoming task to the subject.

At the preliminary stage prior to entering the MRI scanner, each subject was thoroughly acquainted by a neuropsychologist (the first author) with the type and sequence of the tasks: in a separate room all the tasks to be administered later during the fMRI examination were demonstrated on a computer screen using the same parameters.

At the next, so-called executive stage the fMRI examination was performed using the ultrafast echo planar imaging (EPI) sequence that allows one to collect data from the whole brain volume at a sampling interval of 3 seconds. Since every task consisted of six 30-second activation blocks alternating with 30 -second resting periods, then for each task measuring a particular language function, a total of 3360 images were obtained. A 1.5 T MRI scanner made by Philips was used to perform functional (EPI) sequences with 4-mm slice thickness and 1-mm interslice (interstice) gap, as well as T1-weighted structural scans with slice thickness/gap $1 \mathrm{~mm} / 0 \mathrm{~mm}$.
The obtained scans were registered on appropriate data carriers so that they could be available at any time.

\section{Data analysis procedure}

Data analysis is an essential part of the executive stage of the fMRI examination. Figure 1 presents a diagram of the fMRI data analysis procedure.

The data processing procedure is a complex sequence including:

1. Preliminary processing, i.e. (a) head movement correction - during the fMRI scanning that takes about 20 min the subject performs involuntary head movements, which may result in a distorted spatial orientation of the collected images; (b) normalization, i.e. transformation of the subject's 3D brain scan parameters so as to approximate those of a standard brain as much as possible; (c) smoothing - a process aimed at reduction of differences in voxel intensity between particular images by imposing the Gaussian-Kernel mask, which results in an increment in the signal-tonoise ratio.

2. Statistical analysis - using a linear model, comparisons are made between the signal intensity measured in particular voxels under specified experimental conditions;
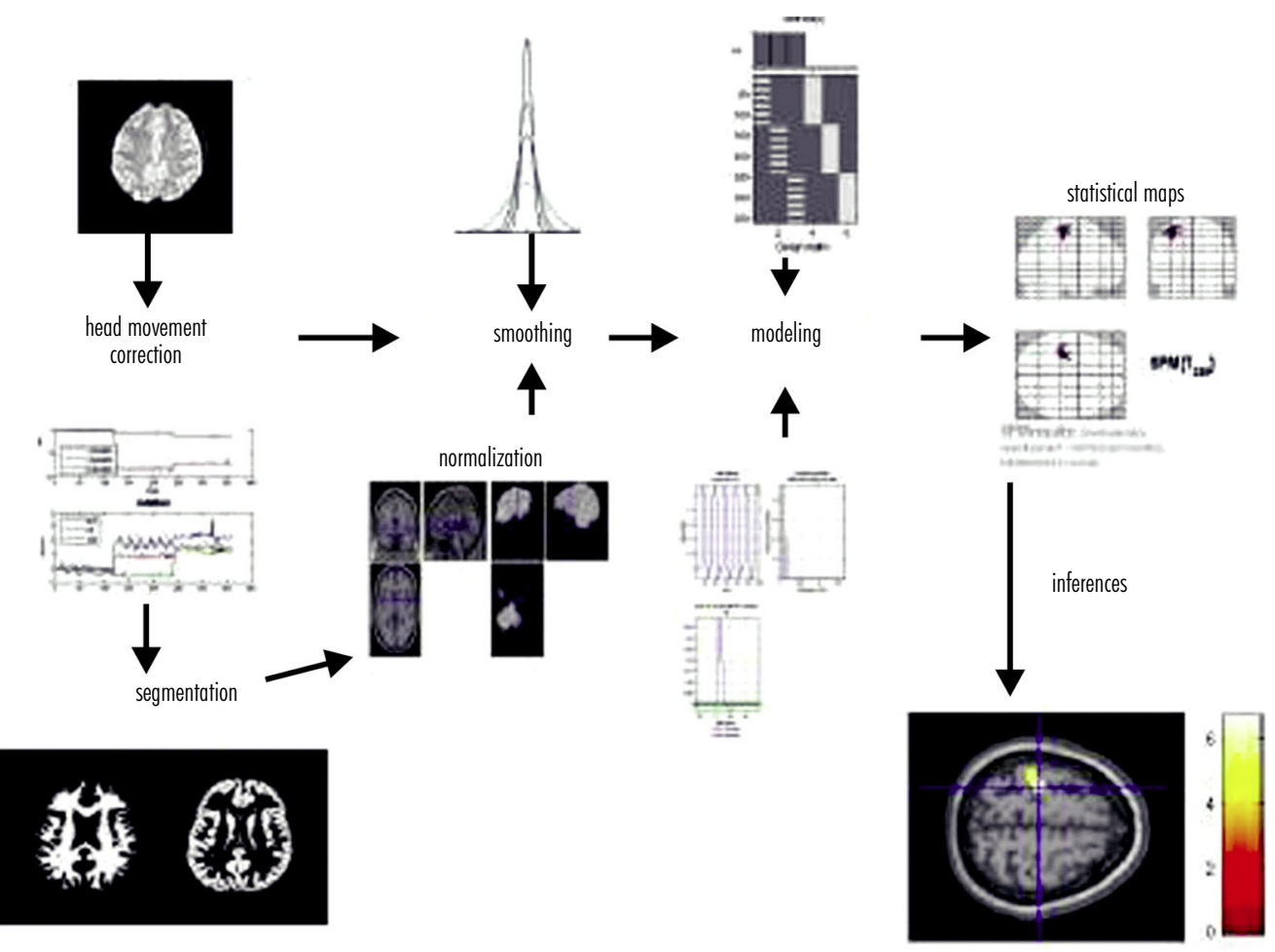

Fig. 1. Diagram of the fMRI data 
significance of differences between particular voxels was assessed using the t-test for independent samples.

3. Visualization - imposition of the statistical activation map on the standard brain image (in comparative studies) or on the individual patient's brain scan (in clinical studies).

Data obtained under this study design were statistically analysed using a specially developed algorithm firstly, for each participant separately. A group analysis of data obtained from the whole sample for each task (i.e. for particular language functions separately) is planned on the study completion.

The Statistical Parametric Mapping (SPM) software running in a MATLAB environment and designed for analysis of imaging data (including fMRI results) was applied in the analyses. (Preparation of scans directly for analysis and graphic visualization can also be performed using a free MRIcro program).

The next step consists of interpretation of the obtained data using colour-coded maps superimposed on structural brain scans. The maps show cerebral areas in which BOLD phenomena were registered. In the scans, not only activation areas, but also artefacts are visible. Differentiation between the two made by the interpreting team requires knowledge about the BOLD effects, the method and imaging technique limitations, as well as anatomy of the brain. Figure 2 shows fMRI data.

\section{Scanner data analysis}

A valid interpretation of scan data resulting in identification of cerebral structures implicated in performance of a particular task requires knowledge of the BOLD phenomenon, its limitations, and anatomy of the brain. Therefore, interpretation of the obtained activation maps by a radiologist is necessary. The diagnostic process includes a detailed analysis of activations registered during specific tasks, their differentiation from artefacts, and a thorough topographical assessment of the brain.

\section{The pilot study}

The above-described assessment procedure was used in a pilot study of four healthy volunteers. The pilot run revealed the following doubtful points: structural scanning was performed in cross-sectional T1-weighted FSE sequences providing images of the brain structures on which the functional map should be superimposed. The use of a neuronavigation protocol in the scanning process should be considered, as it would eli-
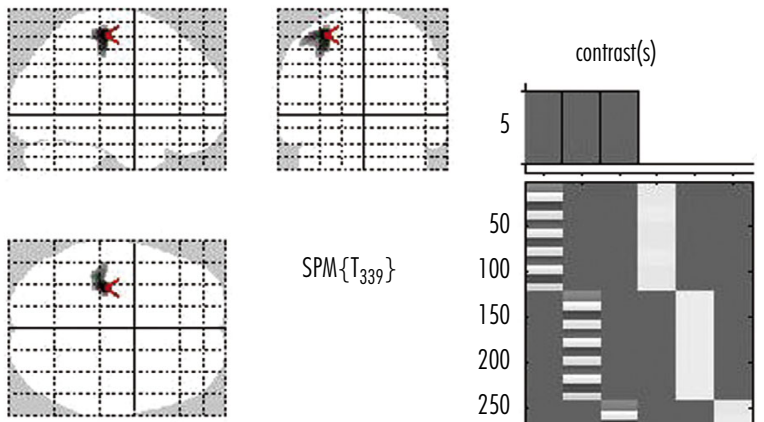

$\operatorname{SPM}\left\{T_{339}\right\}$

\section{0}

100

150

200

250

300

350

50

Right hand movement
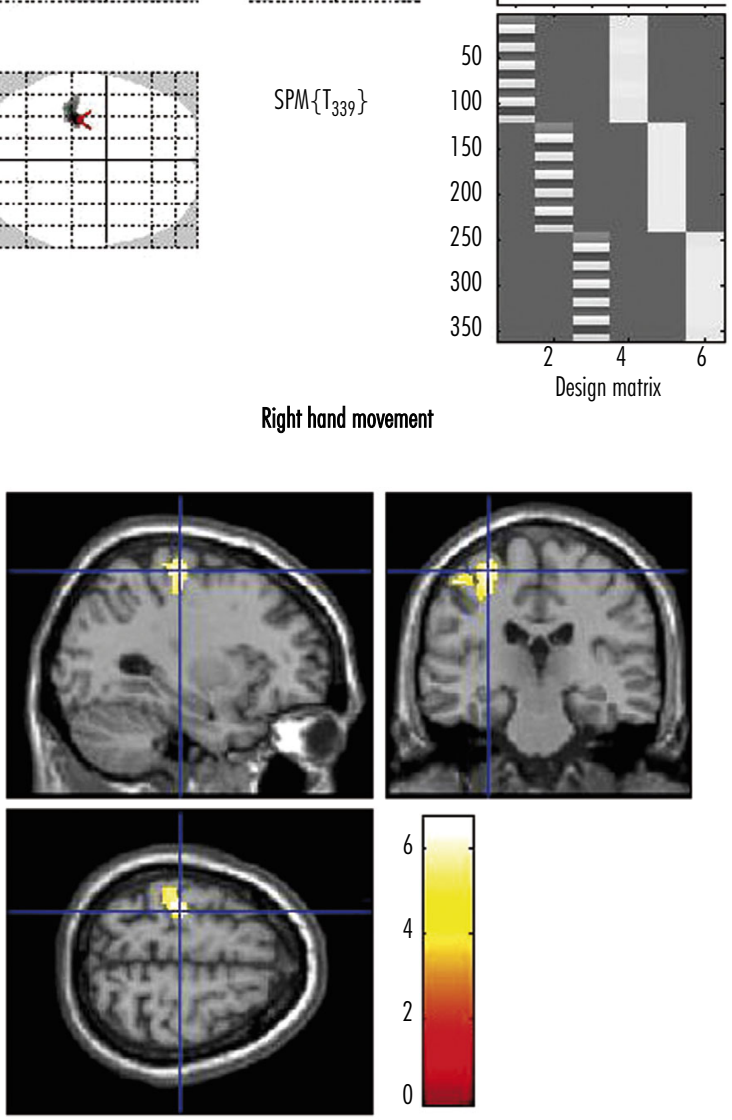

Scans obtained using SPM

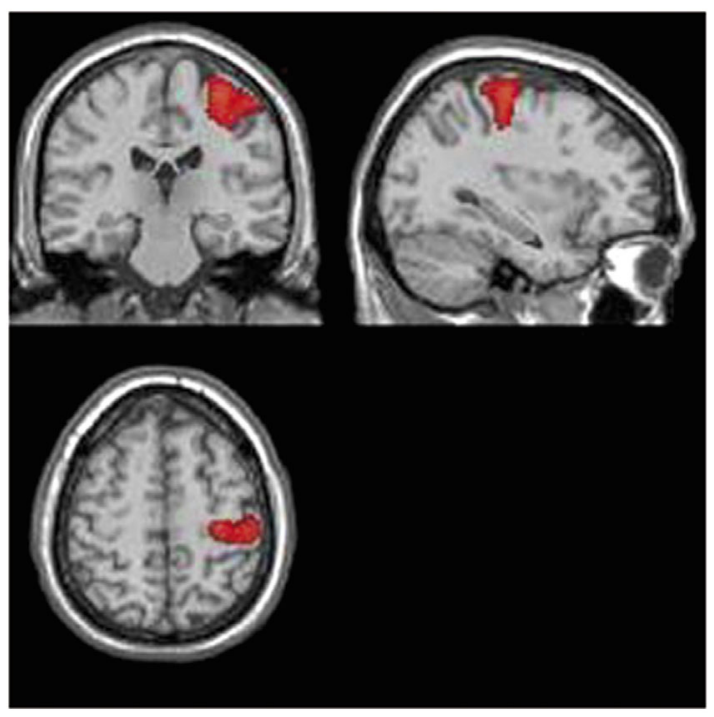

Scans obtained using MRlcro

Fig. 2. Presentation of the fMRI data 
minate the slice thickness artefact (or volume averaging artefact). Also, binoculars used at this preliminary stage for stimulus presentation did not meet the expectations, especially regarding the presentation of complex stimuli necessary for the assessment of some language functions; a projector and a screen for stimulus display seemed to be a definitely better solution, thus the equipment (a camera and a multimedia projector) was adjusted accordingly.

\section{The proper study}

In the proper stage of the study, 10 volunteers were examined using the modified stimulus presentation procedure and equipment. The participants ( 7 men and 3 women, age range: $23-25$ ) had no history of CNS diseases, craniocerebral trauma, or any other perceptible CNS pathology. They were college students or graduates, all were right-handed (except for one left-hander retrained in childhood to use his right hand). Each subject performed all the tasks in succession. The examination (including the subject's positioning and individual adjustment of all the technical parameters) took about 1 hour.

\section{Results}

In each of the tasks designed to measure a separate language function, increased neuronal activation areas were registered. In this preliminary report, averaged re-
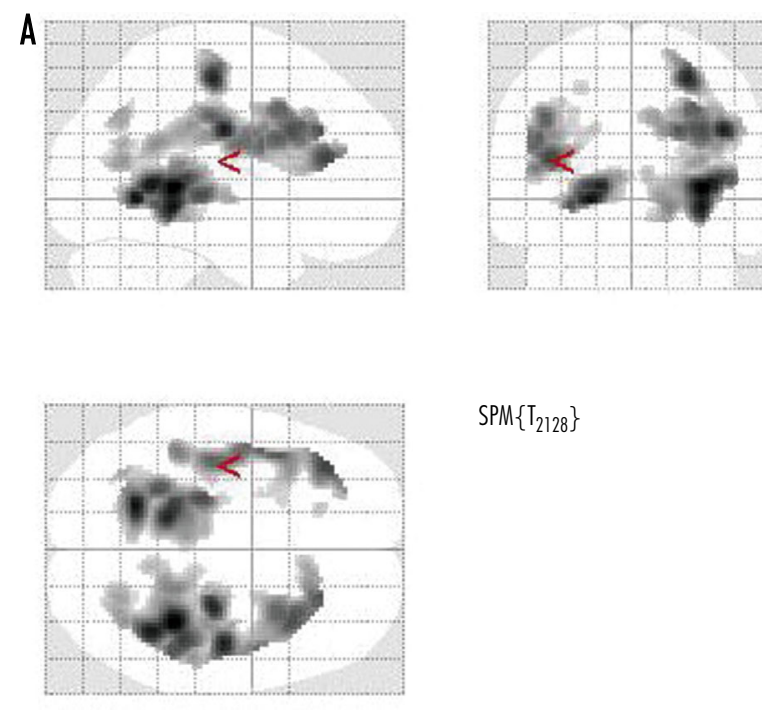

sults of 10 healthy volunteers are presented as an illustration.

For the ability to combine simple language units into more complex ones and the ability to perform the process smoothly, three aspects of the BOLD response are seen in the left cerebral hemisphere in the prefrontal area (the middle and inferior frontal gyri), in the premotor area and in the posterior aspect of the superior and middle temporal gyri (Fig. 3).

For the ability of auditory identification of basic spoken language units - phonemes (i.e. for intact phonematic hearing), increased neuronal activity was found bilaterally, especially in the middle and inferior frontal gyri (prefrontal area), in the posterior-superior temporal gyrus and in the posterior aspect of the superior and middle temporal gyri (Fig. 4).

For the ability of dynamic organization of speech (verbal fluency), increased neuronal activity was found especially in the left hemisphere: in the premotor area, the posterior-superior temporal gyrus and in the posterior aspect of the superior and middle temporal gyri (Fig. 5).

For the ability of word association, increased neuronal activity was found especially in the left hemisphere in the anterior cingulate gyrus (Fig. 6).

For utilizing short-term memory traces, with working memory first and foremost, increased neuronal activity was found bilaterally, especially in the superior parietal lobule, the middle and inferior frontal gyri; activation in older sites is strongly left-lateralized (Fig. 7).

Fig. 3. Brain activation during the reading task analysed using the Statistical Parametric Mapping (SPM) application. A) Activation on the Talairach frame. B) Demonstration of statistically significant activation in three planes. Left and right sides in the transverse and coronal planes are situated inversely to those in standard radiological images 

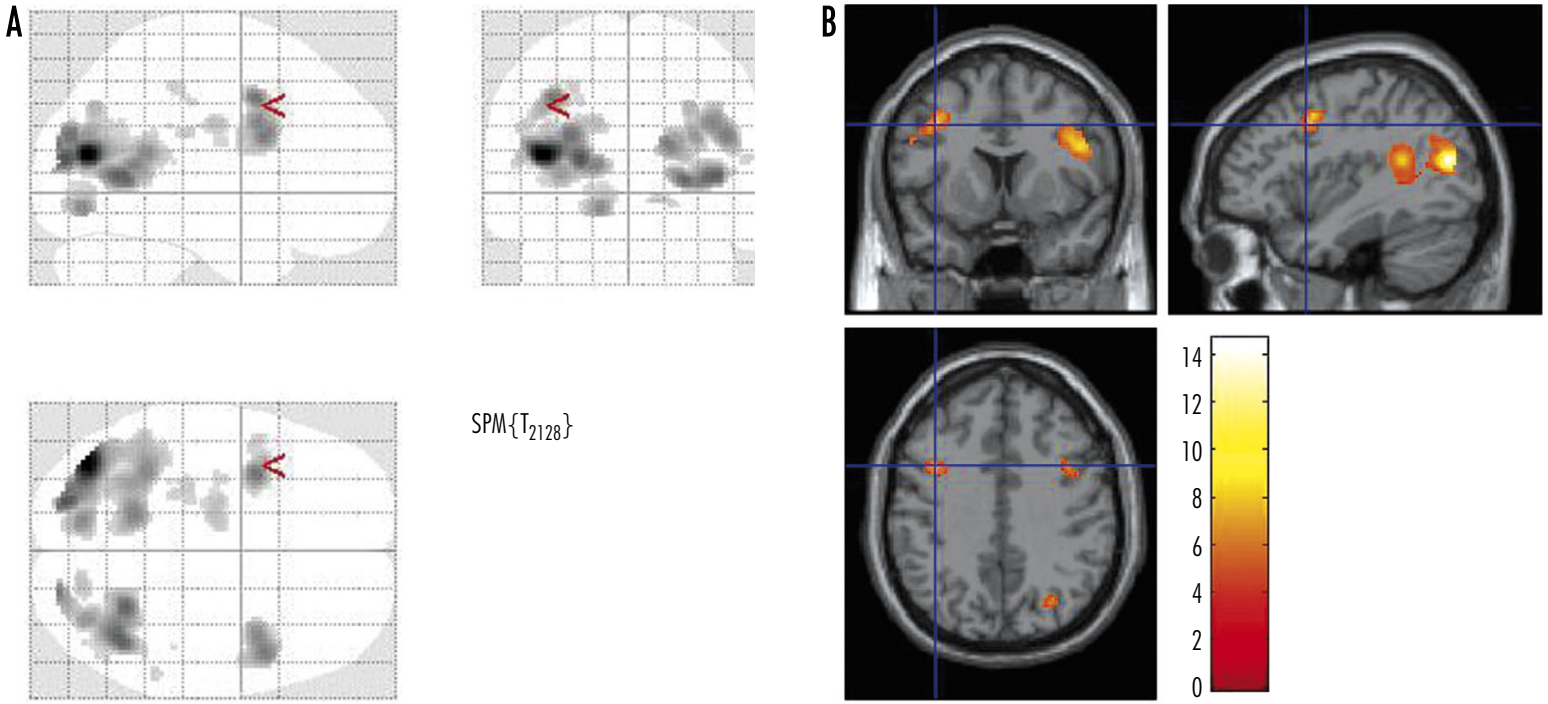

$\operatorname{SPM}\left\{\mathrm{T}_{2128}\right\}$
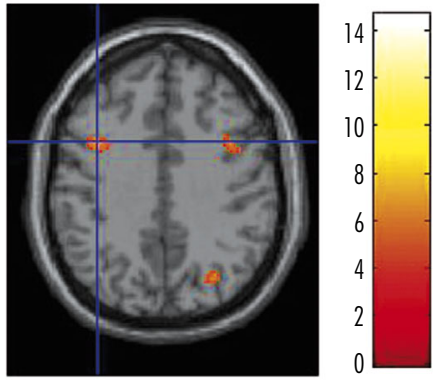

Fig. 4. Brain activation during the phonematic hearing task analysed using the Statistical Parametric Mapping (SPM) application. A) Activation on the Talairach frame. B) Demonstration of statistically significant activation in three planes. Left and right sides in the transverse and coronal planes are situated inversely to those in standard radiological images
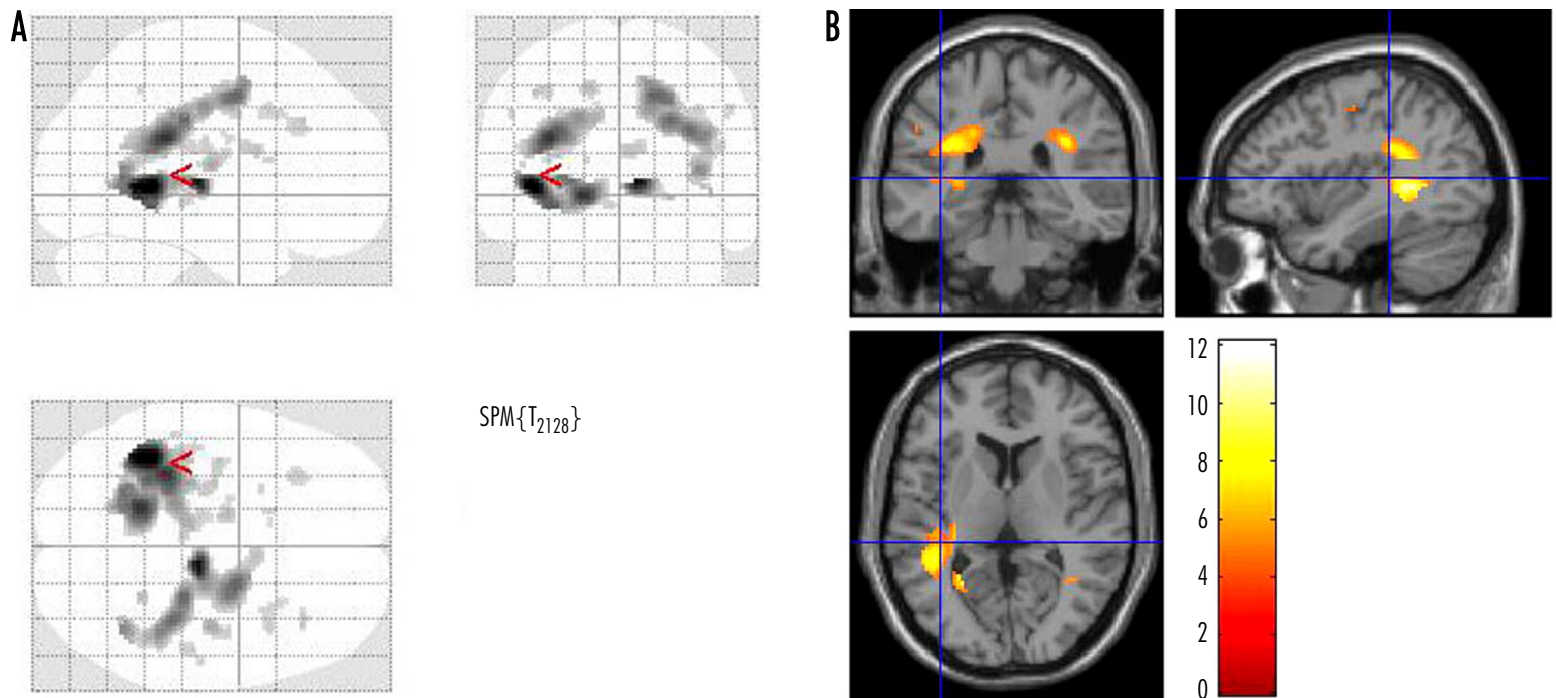

$\operatorname{SPM}\left\{T_{2128}\right\}$
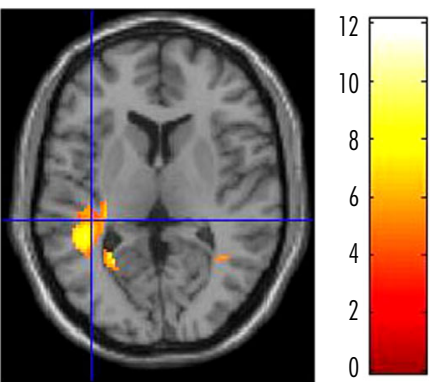

Fig. 5. Brain activation during the verbal fluency task analysed using the SPM application. A) Activation on the Talairach frame. B) Demonstration of statistically significant activation in three planes. Left and right sides in the transverse and coronal planes are situated inversely to those in standard radiological images

For finger tapping, increased neuronal activity was found especially in the left motor area (precentral gyrus) (Fig. 8).

\section{Discussion}

An analysis of scanning data registered using the BOLD technique during performance of specific $\operatorname{cog}$ nitive tasks reveals increased activity areas in different sites of the brain depending on the language functions involved. Obviously, to draw any more general inferences, the study has to be completed and activation areas for particular language functions (i.e. for specific types of tasks used) should be analysed in the whole sample under study. It should be noted, however, that different tasks evoke activation in different cerebral areas. The finding seems interesting since neuronal activation reported in the literature is registered mostly within the inferior frontal 

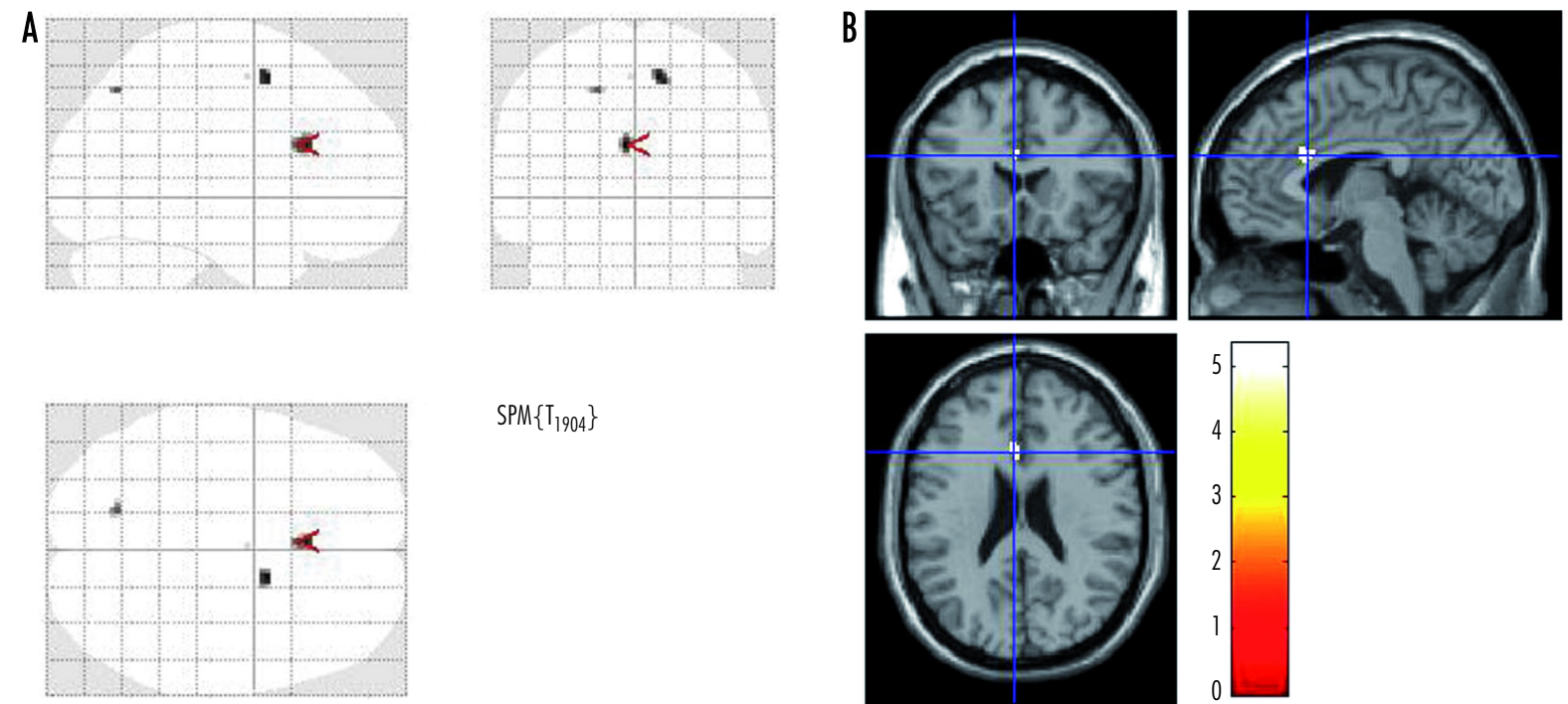

$\operatorname{SPM}\left\{\mathrm{T}_{1904}\right\}$
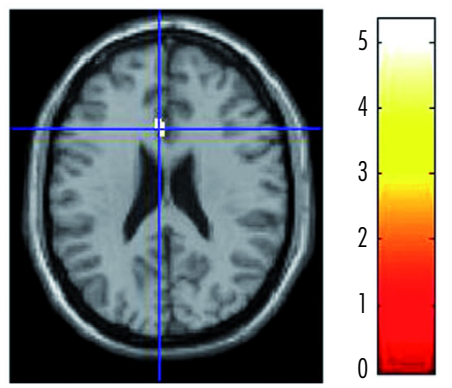

Fig. 6. Brain activation during the task measuring association ability analysed using the SPM application. A) Activation on the Talairach frame. B) Demonstration of statistically significant activation in three planes. Left and right sides in the transverse and coronal planes are situated inversely to those in standard radiological images
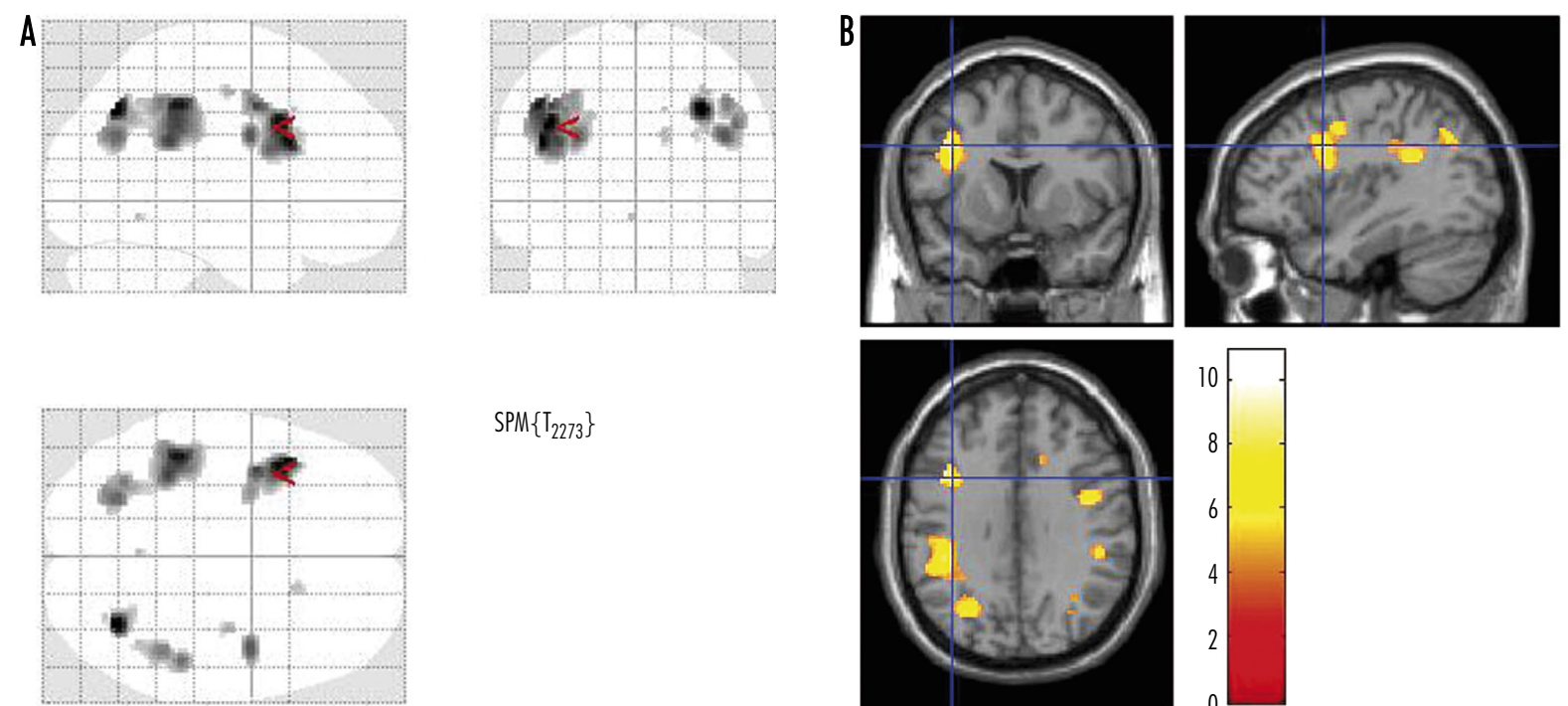

$\operatorname{SPM}\left\{\mathrm{T}_{2273}\right\}$
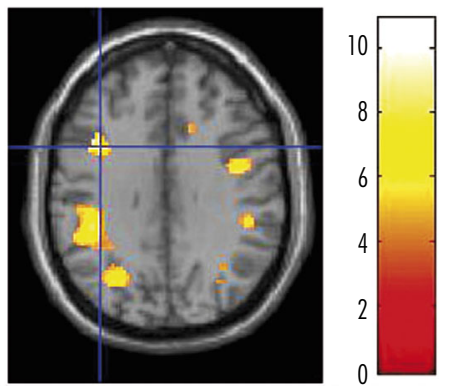

Fig. 7. Brain activation during the short-term memory task analysed using the SPM application. A) Activation on the Talairach frame. B) Demonstration of statistically significant activation in three planes. Left and right sides in the transverse and coronal planes are situated inversely to those in standard radiological images

gyrus (so-called frontal operculum) and is associated with the function of verbal expression (speech, spoken language).

No reports have been published so far presenting evaluation of fMRI scans in terms of other language functions. Since verbal communication disorders may result from impairment of a variety of language functions, the development of specific tasks that investigate such func- tions and are sensitive enough to generate MRI-detectable activation levels seems to be an essential prerequisite of the diagnostic process.

Multifocal neuronal activation seen in brain scans during assessment of cognitive function is due to several factors. Activation of a number of cerebral structures, as well as intricate interactions between different cerebral areas are necessary to perform even a simple task. Human cogni- 

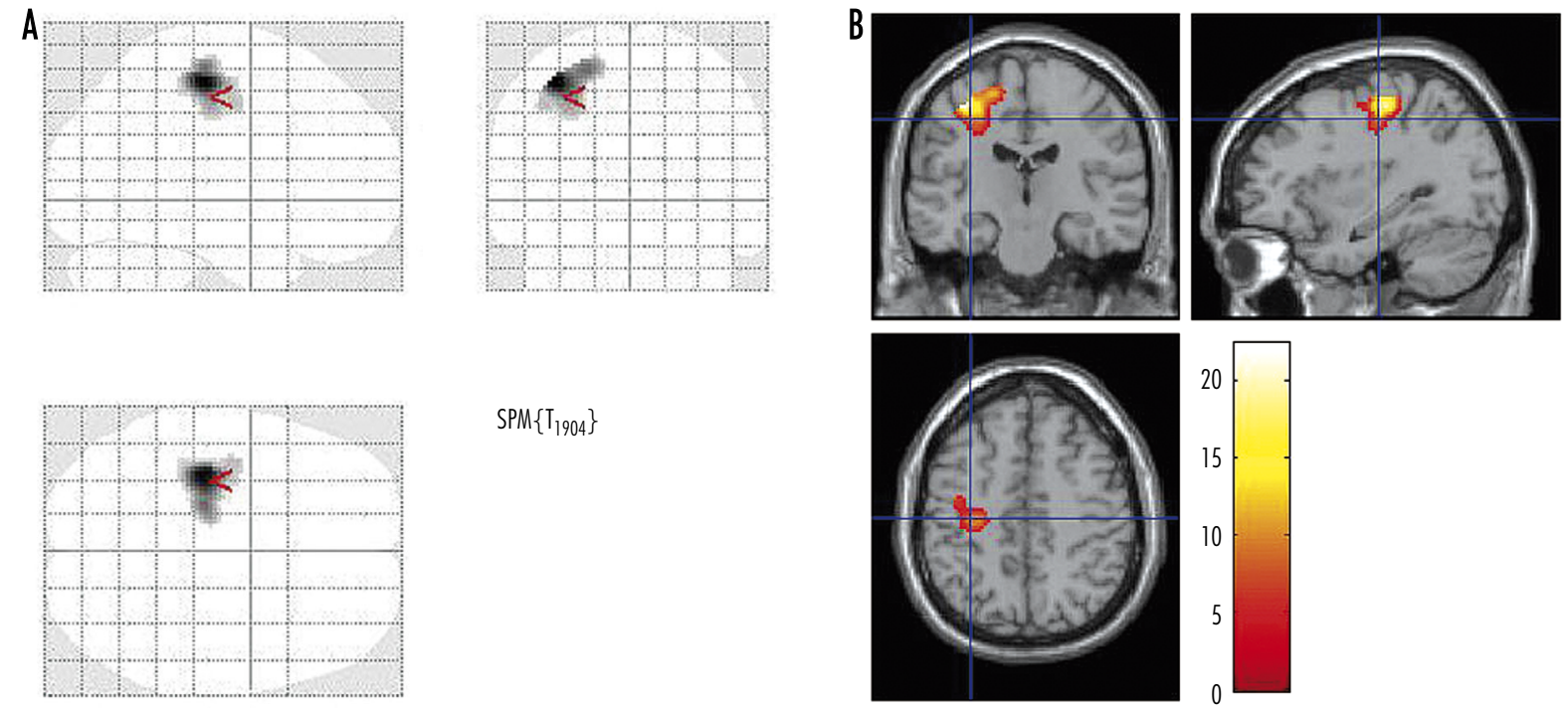

Fig. 8. Brain activation during the finger tapping test (right hand) analysed using the SPM application. A) Activation on the Talairach frame. B) Demonstration of statistically significant activation in three planes. Left and right sides in the transverse and coronal planes are situated inversely to those in standard radiological images

tive functions are usually so complex that their performance is subserved by a dynamic system of co-operating brain structures, not infrequently located in anatomically distant sites. As mentioned earlier, the fMRI examination is based on the BOLD phenomenon - the BOLD signal is produced as a result of different amounts of oxygenated and non-oxygenated blood containing different levels of oxyand deoxyhaemoglobin that differ in magnetic characteristics. In some situations, however, differences in oxy- and deoxyhaemoglobin levels are not associated with neuronal activation: the BOLD phenomenon is registered in the vicinity of large venous vessels and sinuses, as well as near choroid plexuses. It should also be noted that in the study 1.5 T MRI apparatus was used and stimuli were presented in the block design, optimal for this system, i.e. providing the best possible signal-to-noise ratio. The block design does not allow one to register in what order (or at what time) particular activations have emerged; in consequence multifocal activation is seen in the brain scan (with evident differences in the signal-to-noise ratios).

Finally, it should be noted that our preliminary study suggests some modifications that should be made both in the examination procedure, and in the administered tasks.

\section{Conclusions}

The differentiated localization of function-related neuronal activity seems interesting and the research worth continuing, since verbal communication failure may result from impairment of any of various language functions, and studies reported in the literature seem to focus on verbal expression only.

\section{Disclosure}

Authors report no conflict of interest.

\section{References}

1. Darby D., Walsh K. Neuropsychology: a clinical approach. Churchill Livingstone, Edinburgh 2005.

2. Berger M.S., Rostomily R.C. Low-grade gliomas: functional mapping resection strategies, extent of resection, and outcome. J Neurooncol 1997; 34: 85-101.

3. McGirt M.J., Chaichana K.L., Attenello F., et al. Extent of surgical resection is independently associated with survival in patients with hemispheric infiltrating low-grade gliomas. Neurosurgery 2008; 63: 700-707.

4. Sanai N., Berger M. Glioma extent of resection and its impact on patient outcome. Neurosurgery 2008; 62: 753-766.

5. Rajan B., Pickuth D., Ashley S., et al. The management of histologically unverified presumed cerebral gliomas with radiotherapy. Int J Radiat Oncol Biol Phys 1994; 28: 405-413.

6. Shaw E., Arusell R., Scheithauer B., et al. Prospective randomized trial of low versus high dose radiation therapy in adults with supratentorial low-grade glioma. J Clin Oncol 2002; 20: 2267-2276.

7. Smith J.S., Chang E.F., Lamborn K.R., et al. The role of extent of resection in the long-term outcome of low-grade hemispheric gliomas. J Clin Oncol 2008; 26: 1338-1345. 
8. Petrella J.R., Shah L.M., Harris K.M., et al. Preoperative functional MR imaging localization of language and motor area: effect on therapeutic decision making in patients with potentially resectable brain tumors. Radiology 2006; 240: 793-802.

9. Ogawa S., Lee T.M., Kay A.R., et al. Brain magnetic resonance imaging with contrast dependent on blood oxygenation. Proc Natl Acad Sci USA 1990; 87: 9868-9872.

10. Langleben D.D., Loughead J.W., Bilker W.B., et al. Telling truth from lie in individual subjects with fast event-related fMRI. Hum Brain Mapp 2005; 26: 262-273.

11. Koten J.W., Wood G., Hagoort P., et al. Genetic contribution to variation in cognitive function: an fMRI study in twins. Science 2009; 323: 1737-1740.

12. Marchewka A., Brechmann A., Nowicka A., et al. False recognition of emotional stimuli is lateralized in the brain: an fMRI study. Neurobiol Learn Mem 2008; 90: 280-284.

13. Mitchell T.M., Shinkareva S.V., Carlson A., et al. Predicting human brain activity associated with the meanings of nouns. Science 2008; 320: 1191-1195. 